\title{
PENALARAN KREATIF MATEMATIK DITINJAU DARI GAYA KOGNITIF: SUATU ANALISIS PROSES BERPIKIR
}

\author{
Nyangnyang Supriatna*1, Ebih Ar Arhasy ${ }^{2}$, Nani Ratnaningsih ${ }^{3}$ \\ ${ }^{123}$ Magister Pendidikan Matematika Universitas Siliwangi \\ 188102010@ student.unsil.ac.id ${ }^{1}, \underline{\text { arhasy55@ gmail.com }}$, $\underline{\text { naniratnaningsih@unsil.ac.id*3 }}$
}

\begin{abstract}
This study aims to describe the thinking processes of students' creative reasoning in solving mathematical problems in terms of cognitive style. This type of research is qualitative with the exploratory method. Data were collected using the think aloud method when students worked on the Creative Reasoning test questions. The results showed that: students with high Field Independent Cognitive Style and students with low Field Independent Cognitive Style were able to determine the length of the pool radius of the number one problem using more than one method and provide the right arguments (Flexibility aspect). novelty aspect), while students with high Dependent Field Cognitive Style and students with low Dependent Field Cognitive Style have not been able to complete the pool radius size contained in question number one. Students with high Field Independent Cognitive Style and low Field Independent Cognitive Style students are able to answer question number two, by proving that not all angles are asked for less than $60^{\circ}$ and are able to provide logical arguments (aspects of Matematical Foundation) (aspects of Flausibility)). Meanwhile students with high dependent field cognitive style and students with low dependent field cognitive style could not determine the angle size of problem number two, so they could not prove the truth of the question given.
\end{abstract}

Keywords: Creative reasoning, cognitive style, Thinking processes.

\begin{abstract}
Abstrak
Penelitian ini bertujuan untuk Mendeskripsikan proses berpikir dari Penlaran Kreatif peserta didik dalam memecahkan masalah matematik ditinjau dari Gaya Kognitif. Jenis penelitian ini termasuk kualitatif dengan metode eksplorasi. Data dikumpulkan dengan menggunakan metode think aloud saat peserta didik mengerjakan soal test Penalaran Kreatif. Hasil penelitian menunjukan bahwa: peserta didik dengan Gaya Kognitif Field Independent tinggi dan peserta didik dengan Gaya Kognitif Field Independent rendah mampu menenentukan ukuran panjang jari-jari kolam dari permasalahan nomor satu dengan menggunakan lebih dari satu cara serta memberikan argumen yang tepat (aspek Flexibility)(aspek Novelty), sedangkan peserta didik dengan Gaya Kognitif Field Dependent tinggi dan peserta didik dengan Gaya Kognitif Field Dependent rendah belum mampu melengkapi ukuran jari-jari kolam yang terdapat pada soal nomor satu. Peserta didik dengan Gaya Kognitif Field Independent tinggi dan peserta didik dengan Gaya Kognitif Field Independent rendah mampu menjawab pertanyaan nomor dua, dengan membuktikan bahwa tidak semua ukuran sudut yang ditanyakan kurang dari $60^{\circ}$ serta mampu memberikan argumen dengan logis (aspek Matematical Foundation)(aspek Flausibility). Sedangkan Peserta didik dengan Gaya Kognitif Field Dependent tinggi dan peserta didik dengan Gaya Kognitif Field Dependent rendah tidak dapat menentukan ukuran sudut dari permasalahan nomor dua, sehingga tidak dapat membuktikan kebenaran dari pertanyaan yang diberikan.
\end{abstract}

Kata kunci : Penalaran kreatif, Gaya kognitif, Proses berpikir 
Jurnal Lebesgue : Jurnal Ilmiah Pendidikan Matematika, Matematika dan Statistika

Nyangnyang Supriatna, Ebih Ar Arhasy, Nani Ratnaningsih

Volume 2, No. 1, April 2021 hal.10-21

DOI Artikel : 10.46306/lb.v2i1.50

\section{PENDAHULUAN}

Matematika sebagai salah satu pelajaran di sekolah yang digunakan untuk mengembangkan proses berpikir peserta didik. Proses berpikir tersebut digunakan untuk memecahkan masalah yang dihadapi pada saat mengerjakan tugas yang diberikan. Sederatan fakta yang telah diungkapkan oleh Ngilawajan (2013) menegaskan bahwa proses berpikir peserta didik dalam proses pembelajaran seringkali diabaikan. Hal yang sama juga disampaikan oleh Safrida, Susanto, \& Kurniati (2015) bahwa proses berpikir dalam pemecahan masalah matematika kurang mendapat perhatian dari para guru. Padahal, matematika sebagai mata pelajaran yang dibelajarkan di sekolah yang mempunyai tujuan untuk membekali peserta didik dengan kemampuan berpikir logis, analitis, sistematis, kritis, dan kreatif selalu melibatkan proses berpikir. Seorang Pendidik mestinya tidak hanya melihat pada akhir ataupun pada proses pembelajaran yang berlangsung secara kasatmata, tetapi juga menelisik pada proses yang lebih spesifik yang sering kali tidak terlihat, yaitu proses berpikir peserta didik.

Selanjutnya, proses berpikir juga bertujuan untuk memecahkan masalah. Berpikir dan pemecahan masalah sungguh merupakan dua hal yang tidak dapat dipisahkan seperti yang diungkapkan oleh Solso (1995) "Thinking and problem solving are two inseparable matters" berpikir sebagai aktivitas mental, menuntut perlu adanya suatu cara konkrit untuk mengetahui bagaimana proses berpikir peserta didik. Dalam memecahkan suatu masalah peserta didik sering mengalami kesulitan yang disebabkan oleh banyak faktor, seperti faktor internal yang berasal dari dalam diri peserta didik maupun faktor eksternal yang berasal dari luar atau lingkungannya. Kesulitan peserta didik memungkinkan terjadinya kesalahan dalam menyelesaikan tugas atau soal yang diberikan (Limardani, dkk 2015). Kurangnya penguasaan materi oleh peserta didik tentunya tidak hanya ditemukan pada materi yang sulit, tetapi juga materi-materi yang sebenarnya bisa dikategorikan mudah.

Berdasarkan hasil wawancara terhadap salah guru mata pelajaran Matematika kelas XI Perbankan SMK Pertiwi Kuningan pada Materi Program Linier dapat ditarik kesimpulan bahwa dalam menyelesaikan soal matematika yang diberikan guru, ada $15 \%$ peserta didik yang mampu memecahkan permasalahan dengan baik, $15 \%$ peserta didik yang mampu menuangkan ide dengan caranya sendiri dalam menyelesaikan soal matematik, dan sekitar $70 \%$ peserta belum mampu mengembangkan gagasan secara terperinci dalam menyelesaikan permasalahan matematik. 
Hasil wawancara tersebut tidak jauh berbeda dengan hasil studi pendahuluan tes penalaran kreatif pada materi SPLTV dengan satu soal uraian yang diberikan kepada peserta didik kelas XII jurusan Perbankan di SMK Pertiwi Kuningan. Hasilnya untuk aspek mathematical foundation (dasar matematis) yaitu $60 \%$ peserta didik mampu menyusun bentuk matematis dari permasalahan yang diberikan. Akan tetapi, peserta didik hanya mampu menyelesaikan pertanyaan tersebut dengan satu alternatif penyelesaian dan hanya $10 \%$ peserta didik peserta didik yang memenuhi aspek flexibility (fleksibel). Kemudian peserta didik lebih cenderung menggunakan cara yang sudah biasa bukan menggunakan penyelesaian unik atau cara baru dari yang lain sehingga peserta didik belum memenuhi aspek novelty (kebaruan). Peserta didik yang mampu mengembangkan suatu argument atau gagasan yang mendukung pilihan dan penerapan strategi terdapat $20 \%$ yang dapat menguatkan alasan bahwa kesimpulan yang diberikan benar atau plausible (masuk akal). Dari hasil analisis pada studi pendahuluan masih banyak peserta didik yang belum memenuhi indikator dari penalaran kreatif, padahal aspek dasar matematis, fleksibel, masuk akal, dan kebaruan merupakan aspek yang sangat penting dimiliki oleh peserta didik dalam menyelesaikan suatu permasalahan yang akan dihadapi oleh peserta didik.

Pentingnnya penalaran kreatif dikemukakan oleh Lithner (2008) bahwa penalaran kreatif memang penting ketika peserta didik membiasakan bernalar secara kreatif maka dapat membuat suatu kesimpulan yang logis. Lithner (2008) mengemukakan pada dasarnya penalaran kreatif berperan dalam menyelesaikan masalah non rutin, hal ini sangat beralasan mengingat bahwa dalam menyelesaikan masalah non rutin peserta didik tidak bisa langsung mengenali solusi masalah melainkan peserta didik harus mengkonstruksi penalarannya. Penalaran kreatif juga cocok dalam situasi bermasalah, dimana semua peserta didik harus diberi kesempatan dan mungkin dipaksa untuk berjuang dalam menyelesaikan tugas-tugas tertentu (Bergqvist, 2008). Hal tersebut didukung juga oleh Haylock (1997) bahwa penalaran kreatif dipandang sebagai proses berfikir dalam memecahkan masalah non rutin. Namun faktanya peserta didik masih kesulitan dalam menyelesaikan soal penalaran kreatif. Hal ini dikemukakan juga oleh Sulistiawati (2014) kebanyakan peserta didik masih kesulitan dalam mengerjakan soal penalaran. Rata-rata persentase kesulitan yang dialami oleh peserta didik dalam mengerjakan soal penalaran adalah $63,25 \%$. Oleh karena itu penalaran kreatif penting diberikan pada peserta didik dalam menyelesaikan tugas atau masalah, terutama masalah yang bersifat non rutin.

Woolfolk (1997) menjelaskan setiap individu memiliki kemampuan yang cepat dan 
Jurnal Lebesgue : Jurnal Ilmiah Pendidikan Matematika, Matematika dan Statistika

Nyangnyang Supriatna, Ebih Ar Arhasy, Nani Ratnaningsih

Volume 2, No. 1, April 2021 hal.10-21

DOI Artikel : 10.46306/lb.v2i1.50

ada pula yang lambat dalam merespons atau menanggapi suatu masalah. Cara-cara yang dilakukan dalam merespons ini juga berkaitan dengan sikap dan kualitas personal. Ia menambahkan bahwa gaya kognitif seseorang dapat menunjukkan perbedaan variasi individu dalam hal perhatian, penerimaan informasi, mengingat, dan berpikir. Gaya kognitif peserta didik yang berbeda-beda dapat mempengaruhi kemampuan peserta didik dalam berpikir dan bernalar dalam menyelesaikan soal atau permasalahan. Hal ini sesuai dengan pendapat Coop dan Sigel (Basir, 2015) gaya kognitif mempunyai korelasi dengan perilaku intelektual dan perseptual. Intelektual terkait dengan kemampuan seseorang dalam berpikir, sedangkan perseptual terkait dengan kemampuan seseorang dalam memandang atau menafsirkan sesuatu. Sedangkan menurut Slameto (2015) Gaya kognitif merupakan variabel penting yang mempengaruhi pilihan-pilihan peserta didik dalam bidang akademik, kelanjutan dalam bidang akademik, bagaimana peserta didik belajar serta bagaimana peserta didik dan guru berinteraksi didalam kelas.

Gaya kognitif dapat dipandang sebagai satu variabel dalam pembelajaran, kedudukannya merupakan variabel karakteristik peserta didik. Gaya kognitif berkaitan dengan perbedaan mendasar dalam ekspektasi hidup individu, hubungan mereka dengan orang lain, dan cara di mana mereka mencari solusi suatu masalah (Saracho, 1998). Gaya kognitif juga sebagai pendekatan individu untuk mengatur dan mewakili informasi. Gaya kognitif berbeda dengan inteligensi dan dimensi kemampuan yang lain. Witkin dan Arsch (1979) membagi gaya kognitif menjadi dua yaitu Field Dipendent dan Field Independent. Witkin membedakan individu yang memiliki gaya kognitif Field Dipendent dan Field Independent melalui kemampuan menjawab Group Embeded Figure Test (GEFT) dalam waktu yang ditentukan serta kriteria tertentu. Beberapa tahun terakhir studi gaya kognitif telah menjadi aliran yang luas dalam psikologi kognitif dan pendidikan matematika. Individu menampilkan gaya kognitif pribadi mereka sendiri, yaitu atribut yang luas yang menjadi nyata dalam respons seseorang terhadap berbagai situasi (Anastasi, 1996).

Untuk itu perlu melakukan penugasan masalah dan penyelesaian tugas. Ketika seorang individu harus menyelesaikan masalah, mereka harus berpikir, menganalisis formulasi secara kritis, memeriksa data formulasi tersebut dan untuk menangani strategi pemecahan yang memungkinkan mendapatkan solusi untuk masalah tersebut. Penyelesaian dan pengajuan masalah membantu memperkuat apa yang sedang dipelajari. Oleh karena itu, Noda (2000) mengemukakan bahwa kedua kegiatan itu penting untuk membangun pengetahuan matematika, yang merupakan tindakan kognitif dasar yang 
Jurnal Lebesgue : Jurnal Ilmiah Pendidikan Matematika, Matematika dan Statistika

Nyangnyang Supriatna, Ebih Ar Arhasy, Nani Ratnaningsih

Volume 2, No. 1, April 2021 hal.10-21

DOI Artikel : 10.46306/lb.v2i1.50

penting untuk teori dan praktik pendidikan. Uraian di atas menunjukkan adanya keterkaitan antara proses berpikir kemampuan penalaran kreatif peserta didik dengan gaya kognitif Field Dipendent dan Field Independent dalam memecahkan masalah matematik.

\section{METODE PENELITIAN}

Penelitian ini menggunakan metode kualitatif deskriptif. Menurut Sugiono, penelitian kualitatif adalah penelitian dimana peneliti ditempatkan sebagai instrument kunci, teknik pengumpulan data dilakukan secara penggabungan dan analisis data bersifat induktif (Sugiono, 2019). Menurut Poerwandari (2005), penelitian kualitatif menghasilkan dan mengolah data yang sifatnya deskriptif, seperti transkripsi wawancara dan observasi. Denzin \& Licoln (dalam Moleong, 2017) mengemukakan bahwa penelitian kualitatif adalah penelitian yang menggunakan latar alamiah dengan tujuan menerjemahkan fenomena yang terjadi. Selain itu, Williams (dalam Moleong, 2017) mengemukakan bahwa penelitian kualitatif adalah pengumpulan data dari latar alamiah dengan metode alamiah dan dilakukan oleh peneliti yang tertarik secara alamiah. Selanjutnya peneliti akan mendeskripsikan data tentang proses berpikir penalaran kreatif matematik pada materi SPLTV ditinjau dari gaya kognitif.

Subjek penelitian ini diambil dari 30 peserta didik kelas XI SMK Pertiwi Kuningan tahun ajaran 2020/2021 semester ganjil yang telah diberikan angket gaya kognitif. Dipilihnya peserta didik kelas XI karena pada umumnya peserta didik kelas XI berusia antara 15 - 17 tahun berada pada tahap operasional formal (formal operational stage), pada tahap ini individu melampaui dunia nyata, pengalaman-pengalaman konkrit dan berfikir secara abstrak dan lebih logis, sebagai bagian dari tahap perkembangan formal sesuai dengan tahap perkembangan intelegensi dan pengetahuan menurut Piaget (Ismail, 2019). Selain itu, dipilihnya subjek kelas XI karena peserta didik pada kelas ini dianggap telah cukup memiliki pengetahuan yang diperlukan dalam menyelesaikan tugas yang berkaitan dengan penalaran kreatif. Proses pemilihan subjek penelitian diawali dengan memberikan angket gaya kognitif yang menggunakan instrumen GEFT yang dikembangkan oleh Witkin, et.al yang terdiri dari 25 item. Kriteria yang digunakan dalam pemilihan subjek menggunakan kriteria menurut Kepner dan Neimark (Basir, 2015) yaitu subjek yang dapat menjawab benar $0 \leq F D \leq 9$ digolongkan field dependent (FD) dan $10 \leq F I \leq 18$ digolongkan field independent (FI). Data ini dianalisis dengan menggunakan kriteria sebagai berikut, subjek penelitian yang menjawab skor benar 
Jurnal Lebesgue : Jurnal Ilmiah Pendidikan Matematika, Matematika dan Statistika

Nyangnyang Supriatna, Ebih Ar Arhasy, Nani Ratnaningsih

Volume 2, No. 1, April 2021 hal.10-21

DOI Artikel : 10.46306/lb.v2i1.50

sebanyak $\quad 0 \leq F D$ rendah $\leq 4$ digolongkan $\quad F D$ rendah, $0 \leq F D$ tinggi $\leq 4$ digolongkan FD tinggi, $10 \leq$ FI rendah $\leq 14$ digolongkan FI rendah, dan $15 \leq$ FI ting $i \leq 18$ digolongkan FI tinggi.

Kemudian dipilih peserta didik sebagai subjek penelitian, yang mewakili masingmasing gaya kognitif field dependent dan field independent sebagai subjek penelitian sebanyak 2 subjek penelitian dari masing-masing FD rendah dan FD tinggi, dan 2 subjek penelitian dari FI rendah dan FI tinggi. Setelah semua kriteria gaya kogitif terpenuhi kemudian setiap peserta didik yang mewakili kriteria gaya kognitif dijadikan sebagai sabjek penelitian, kemudian subjek penelitian diberikan soal tes penalaran kreatif matematik dan diwawancarai.

Teknik analisis data yang dilakukan dengan cara: yaitu: (1) Proses pengolahan data dan analisis data angket (2) Hasil tes penalaran kreatif setiap subjek penelitian dianalisis berdasarkan pengkodean proses berpikir peserta didik yang telah dibuat peneliti. Hasil analisis berupa gambaran atau deskripsi hasil tes penalaran kreatif peserta didik yang tertuang dalam tulisan tersebut, dan (3) Dalam analisis data hasil wawancara, peneliti menggunakan model interactive model, yang unsur-unsurnya meliputi reduksi data (data reduction), penyajian data (data display), dan conclutions drowing/verifiying.

Pengecekan keabsahan data menggunakan triangulasi teknik, untuk menguji kredibilitas data dilakukan dengan cara mengecek data kepada sumber yang sama dengan teknik yang berbeda. Misalnya untuk mengecek data bisa melalui wawancara, observasi, dokumentasi. Bila dengan teknik pengujian kredibilitas data tersebut menghasilkan data yang berbeda, maka peneliti melakukan diskusi lebih lanjut kepada sumber data yang bersangkutan untuk memastikan data mana yang dianggap benar.

\section{HASIL DAN PEMBAHASAN}

Subjek pada penelitian ini berjumlah 4 orang yang terdiri 2 orang peserta didik yang memiliki Gaya Kognitif Field Independent dan 2 orang peserta didik memiliki Gaya Kognitif Field Dependent. Empat subjek tersebut diberikan tes Penalaran Kreatif matematik yang dianalisis proses berpikirnya. Dari empat peserta didik sebagai subjek penelitian berikut rakapitulasi banyaknya peserta didik yang memecahkan masalah perindikator Penalaran Kreatif.

Empat subjek yang mewakili Gaya Kognitif Field Independent dan Field Dependent diberikan tes penalaran kreatif matematik. Bersamaan dengan itu, peneliti mengamati proses berpikir dari peserta didik yang sedang menyelesaikan soal tes yang diberikan. Dari 
Jurnal Lebesgue : Jurnal Ilmiah Pendidikan Matematika, Matematika dan Statistika

Nyangnyang Supriatna, Ebih Ar Arhasy, Nani Ratnaningsih

Volume 2, No. 1, April 2021 hal.10-21

DOI Artikel : 10.46306/lb.v2i1.50

empat peserta didik sebagai subjek penelitian berikut rakapitulasi banyaknya peserta didik yang memecahkan masalah perindikator Penalaran Kreatif.

Tabel 1 Jumlah Peserta Didik Memecahkan Masalah PerIndikator

\section{Indikator Penalaran Kreatif Tidak Menjawab Menjawab}

\begin{tabular}{lll}
\hline Flexsibel (Flexibility) & 2 & 2 \\
\hline Kebaruan (Novelty) & 4 & 0 \\
\hline $\begin{array}{l}\text { Dasar Matematis (Mathematical } \\
\text { Foundations) }\end{array}$ & 1 & 3 \\
\hline Masuk akal (Plausible) & 2 & 2 \\
\hline
\end{tabular}

Berdasarkan tabel 1 menunjukan subjek yang memecahkan masalah tes penalaran kreatif matematik untuk masing-masing indikator. Dari empat indikator penlaran kreatif, terdapat satu masalah pada indikator Novelty (kebaruan) yaitu sebanyak empat peserta didik tidak menjawab. Sedangkan pada tiga indikator berikutnya, yaitu pada indikator Dasar Matematis (Mathematical Foundations), peserta didik yang mampu menjawab ada tiga orang. Pada indikator Flexsibel (Flexibility), peserta didik yang mampu menjawab hanya ada dua orang. Kemudian pada indikator Masuk akal (Plausible) ada dua peserta didik yang mampu menjawab. Peneliti coba bertanya kepada keempat peserta didik tersebut hampir kebanyakan sangat sulit untuk dijawab. Kebanyakan peserta didik tidak menyukai masalah yang menurut mereka soal rumit dan soal penerapan berbagai aplikasi rumus atau soal kombinasi bangun karena membutuhkan waktu yang lama untuk memahami dan mengerjakannya.

Alur dari proses berpikir penalaran kreatif yang harus dilakukan peserta didik dalam memecahkan masalah matematik ditinjau dari gaya kognitif disajikan pada Gambar 1 berikut:

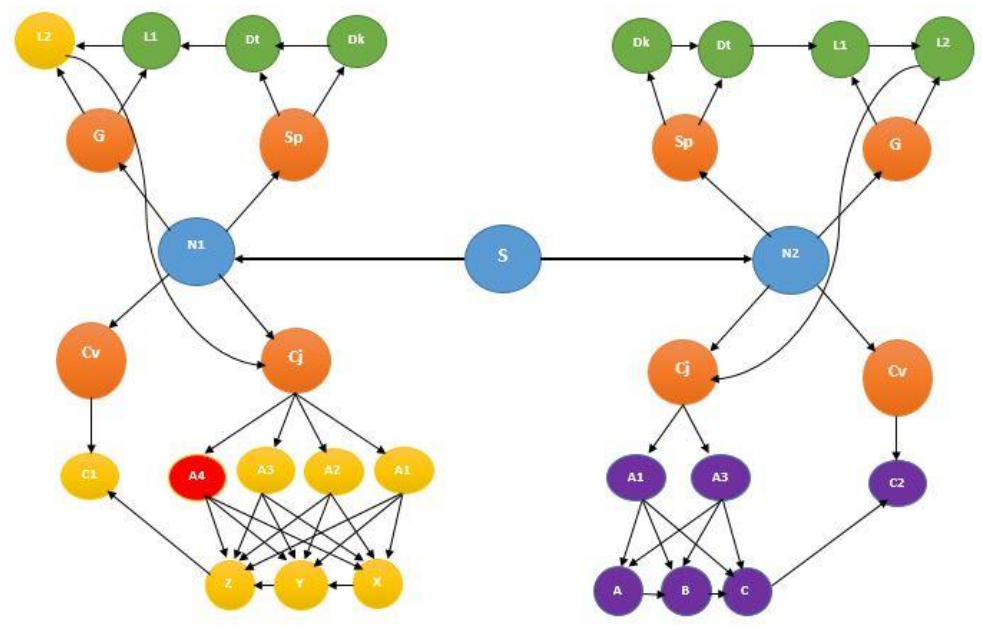


Jurnal Lebesgue : Jurnal Ilmiah Pendidikan Matematika, Matematika dan Statistika

Nyangnyang Supriatna, Ebih Ar Arhasy, Nani Ratnaningsih

Volume 2, No. 1, April 2021 hal.10-21

DOI Artikel : 10.46306/lb.v2i1.50

Gambar 1 kerangka proses berpikir penalaran kreatif

Gambar 1 merupakan kerangka proses berpikir penalaran kereatif yang dibuat peneliti dan merupakan proses penyelesaian yang benar. Lingkaran biru menunjukan soal penalaran kreatif, lingkaran coklat menunjukan aspek proses berpikir, lingkaran hijau menunjukan aspek Mathematical Foundation dari penalaran kreatif, lingkaran kuning menunjukan aspek Flexibility dari penalaran kreatif, lingkaran merah menunjukan aspek Novelty dari penalaran kreatif, lingkaran ungu menunjukan aspek Plausible dari penalaran kreatif dan lingkaran putih tidak menunjukan aspek dari penalaran kreatif. Sedangkan keterangan untuk pengkodean penyelesaian soal yaitu sebagai berikut: S (Soal Penalaran Kreatif); N1, N2 (Soal Nomor 1 dan 2); Sp, G, Cj, Cv (Aspek Specializing, Generalizing, Conjecturing, dan Convincing); Dk, Dt, L1, L2, A1, A2, A3, dan A4 (Diketahui, Ditanyakan, Langkah 1, Langkah 2, Substitusi, Eliminasi, Gabungan Substitusi dan Eliminasi, Determinan); A, B, C, X, Y, Z (nilai sudut A, nilai sudut B, nilai sudut C, nilai $\mathrm{X}$, nilai Y, nilai Z); C1 dan C2 (kesimpulan soal nomor 1, kesimpulan soal nomor 2). Selanjutnya dibandingkan dengan hasil penyelesaian setiap subjek pada setiap nomor. Proses berpikir penalaran kreatif dalam penelitian ini adalah sebagai berikut :

\section{a. Specializing}

Mason mengemukakan tahap proses berpikir yang pertama adalah specializing. Pada tahap ini peserta didik mampu menghususkan permasalahan yang disajikan menjadi susunan bagian seperti apa yang diketahui dan apa yang ditanyakan. Berdasarkan analisis, seluruh subjek telah mampu memahami masalah dengan menuliskan apa yang diketahui dan apa yang ditanyakan dari permasalahan yang ditanyakan. Keempat subjek telah memenuhi indikator penalaran kreatif yaitu Matematical Foundation.

\section{b. Generalizing}

Generalizing merupakan kegiatan mencari langkah-langkah penyelesaian dan bagaimana menguji langkah-langkah kebenaran atas dugaan penyelesaian yang telah dibuat. Subjek 1 dengan gaya kognitif field independent tinggi dan subjek 2 dengan gaya kognitif field independent rendah dapat menentukan langkah-langkah penyelesaian dari indikator proses berpikir menurut mason, sedangkan S3 dan S4 belum mempu melalui tahap ini. Selain itu S1 dan S2 mereka mampu membuat beberapa alternatif jawaban atau aspek Flexsibility yang merupakan indikator dari penalaran kreatif. Sedangkan untuk aspek Novelty belum ada yang dapat memenuhinya. 
Jurnal Lebesgue : Jurnal Ilmiah Pendidikan Matematika, Matematika dan Statistika

Nyangnyang Supriatna, Ebih Ar Arhasy, Nani Ratnaningsih

Volume 2, No. 1, April 2021 hal.10-21

DOI Artikel : 10.46306/lb.v2i1.50

\section{c. Conjecturing}

Conjecturing merupakan kegiatan membuat dugaan dari pola yang telah dibuat. Dari hasil analisis subjek 1 dengan gaya kognitif field independent tinggi dan subjek 2 dengan gaya kognitif field independent rendah dapat membuat dugaan jawaban yang tepat untuk menyelesaikan soal penelaran kreatif matematik yang diberikan. Subjek 1 dengan gaya kognitif field independent tinggi dan subjek 2 dengan gaya kognitif field independent rendah belum menunjukan ide unik dalam menyelesaiakan masalahan sebagai salah satu indikator Novelty dalam penalaran kreatif. Subjek 3 dengan gaya kognitif field dependent tinggi dan subjek 4 dengan gaya kognitif field dependent rendah belum mampu membuat duagaan yang tepat dalam menyelesaikan permasalahan, namun mereka dapat melalui tahapan proses berpikir cojecturing.

\section{d. Convincing}

Convincing merupakan kegiatan menjelaskan alasan penyelesaian berdasarkan konsep-konsep matematika. Lithner mengemukakan harus ada alasan yang kuat sebagai argumen yang mendukung pilihan dan penerapan strategi sehingga kesimpulan yang diberikan benar dan masuk akal (Plausible). Dari hasil analisis, subjek 1 dengan gaya kognitif field independent tinggi dan subjek 2 dengan gaya kognitif field independent rendah mampu membuat alasan yang kuat dan masuk akal sehingga diperoleh kesimpulan yang benar. Sedangkan subjek 3 dengan gaya kognitif field dependent tinggi dan subjek 4 dengan gaya kognitif field dependent rendah belum mampu menyelesaikan permasalahan dan membuat kesimpulan yang benar.

Proses berpikir penalaran kreatif peserta didik S1, S2, S3 dan S4 dalam menyelesaikan permasalahan disajikan pada Gambar 2 berikut:

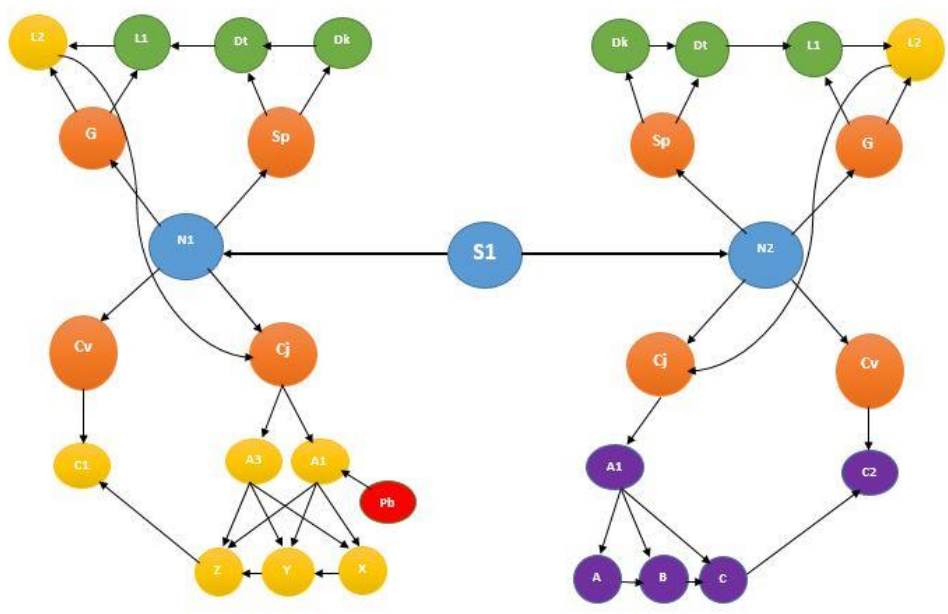




\section{Gambar 2 Proses berpikir Penalaran kreatif Peserta Didik S1}

Proses berpikir penalaran kreatif berdasarkan hasil analisis, terlihat proses berpikir yang dilakukan S1/FI tinggi mampu menyelesaikan permasalahan yang diberikan dengan membuat alternatif jawaban lebih dari satu dengan hasil yang tepat. S1/FI tinggi juga dapat memenuhi aspek penalaran kreatif Flexibility (fleksibel), namun untuk aspek Novelty (kebaruan) belum terpenuhi. Kemudian untuk tahapan proses berpikir menurut Mason meliputi Specializing, Generalizing, Conjecturing dan Convincing dapat dikukan dengan baik. Kemudian S1/FI tinggi juga mampu membuat penyelesaian dan memberikan argumen serta penjelasan yang logis dan masuk akal dalam menyimpulkan hasil pekerjaan dalam menjawab masalah yang diberikan. Pada tahap ini S1/FI tinggi mampu memenuhi aspek penalaran kreatif Mathematical Foundation dan Plausible.

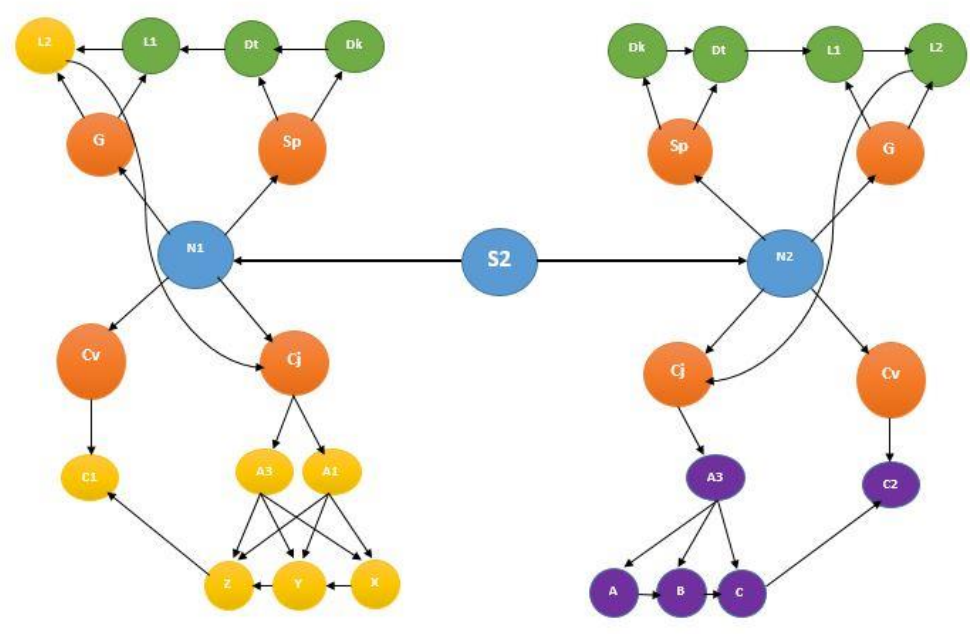

Gambar 3 Proses berpikir Penalaran kreatif Peserta Didik S2

Berdasarkan hasil analisis kategori jawaban, S2 dengan gaya kognitif Field Independent rendah mampu menentukan penyelesaian dari permasalahan yang ditanyakan dengan menggunakan dua cara, walaupun cara satu ada beberapa kesalahan namun telah dilengkapi dan diselesaikan. Pada tahap ini S2/FI rendah telah memenuhi aspek Flexibility dari penalaran kreatif, sedangkan untuk aspek Novelty belum terpenuhi. S2/FI rendah mampu menjawab permasalahan dengan tepat, dan memberikan argumen yang logis dalam memberikan kesimpulan. Sehingga aspek penalaran kreatif Mathematical Foundation dan Plausible dapat dipenuhi. Kemudian untuk tahapan proses berpikir menurut Mason meliputi Specializing, Generalizing, Conjecturing dan Convincing dapat dilalui dengan baik. 


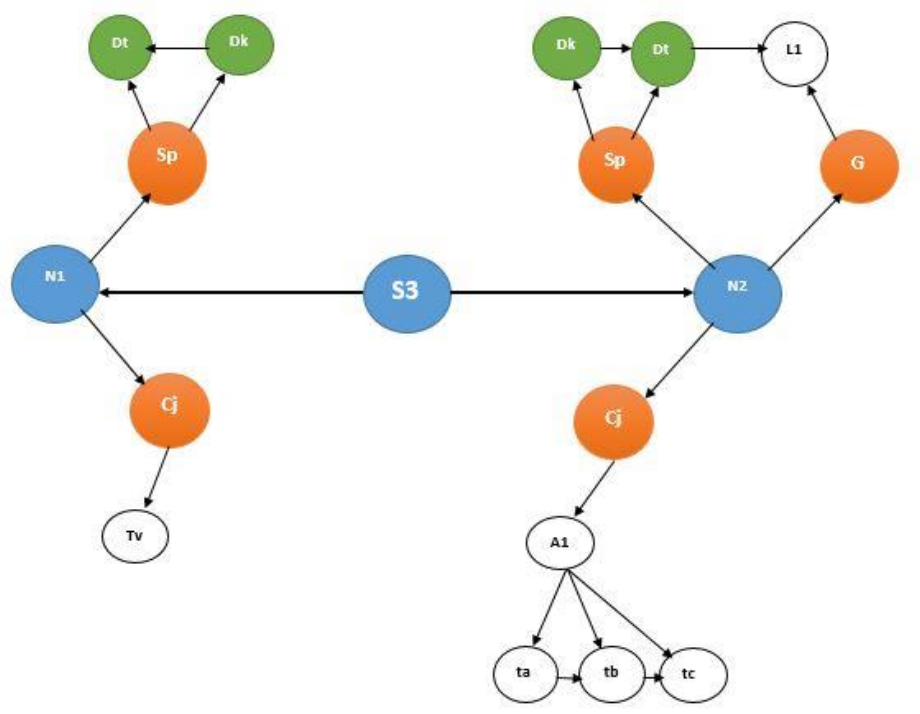

Gambar 4 Proses berpikir Penalaran kreatif Peserta Didik S3

Peserta didik S3 dengan Field Dependent tinggi belum mampu menentukan penyelesaian dari permasalahan yang diberikan. Kemudian S3/FD tinggi hanya mampu membuat satu persamaan yang betul dan dua lagi belum tepat serta belum bisa membuktikan kebenaran dari permasalahan yang ditanyakan sehingga aspek dari penalaran kreatifnya belum terpenuhi. Berdasarkan hasil analisis, S3/FD tinggi telah memenuhi satu aspek penlaran kreatif Mathematical Foundation namun belum memenuhi aspek penalaran kreatif Flexibility, Novelty dan Plausibe. Pada tahap proses berpikir juga S3/FD tinggi hanya melalui tahapan proses berpikir Specializing, generalizing dan Conjecturing, sedangkan tahap Convincing belum terpenuhi karena langkah-langkah penyelesaian yang dilakukan belum tepat dalam menjawab pertanyaan dari permasalahan.

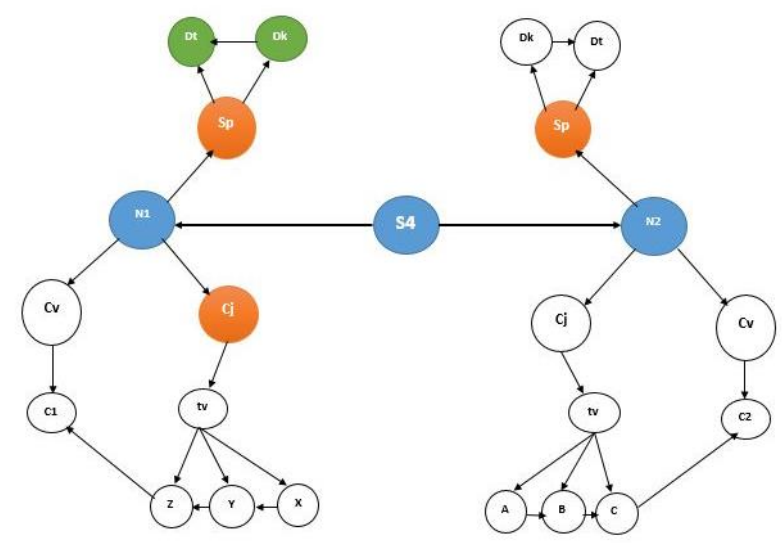

Gambar 5 Proses berpikir Penalaran kreatif Peserta Didik S4

Proses berpikir penalaran kreatif peserta didik dengan gaya kognitif Field dependent rendah belum mampu menentukan penyelesaian yang ditanyakan. Pada tahap ini S4 
Jurnal Lebesgue : Jurnal Ilmiah Pendidikan Matematika, Matematika dan Statistika

Nyangnyang Supriatna, Ebih Ar Arhasy, Nani Ratnaningsih

Volume 2, No. 1, April 2021 hal.10-21

DOI Artikel : 10.46306/lb.v2i1.50

dengan gaya kognitif field dependent rendah belum memenuhi aspek Flexibility dan aspek Novelty. Selanjutnya S2/FD rendah juga belum mampu menjawab masalah yang disajikan, hasilnya S4 tidak mampu memberikan argumen yang logis dalam memberikan kesimpulan. Sehingga hal tersebut mengakibatkan aspek penalaran kreatif Mathematical Foundation dan Plausible tidak dapat dipenuhi. Pada tahap proses berpikir S4 dengan gaya kognitif field dependent rendah hanya meliputi sebagian tahap Specializing dan Conjecturing.

\section{KESIMPULAN}

Proses berpikir pada tahap specializing seluruh subjek dapat menuliskan komponen yang diketahui dan ditanyakan sehingga memenuhi aspek Matematical Foundation dari penalaran kreatif. Tahap Generalizing, subjek 1 field independent tinggi dan subjek 2 field independent rendah mampu membuat langkah-langkah penyelesaian dari permasalahan yang diberikan dan memenuhi aspek Flexibily. Tahap Conjecturing, subjek 1 field independent tinggi dan subjek 2 field independent rendah mampu membuat dugaan jawaban yang tepat, sedangkan untuk aspek Novelty semua subjek belum mampu untuk memenuhinya. Tahap Convincing, subjek 1 dengan gaya kognitif field independent tinggi dan subjek 2 dengan gaya kognitif field independent rendah mampu membuat alasan yang kuat dan masuk akal (Plausible) sehingga diperoleh kesimpulan yang benar.

\section{DAFTAR PUSTAKA}

Anastasi, A. (1996): Psychological testing. 7th edition. New York: Macmillan

Basir, M A (2015) Kemampuan Penalaran Siswa Dalam Pemecahan Masalah Matematis Ditinjau Dari Gaya Kognitif. Jurnal Pendidikan Matematika Unissula. 3 (1): 106114

Bergqvist, T.; Lithner, J.; Sumpter, L., (2008). Upper Secondary Students' Task Reasoning, International journal of mathematical education in science and technology, 39 (1), 1-12 URL: http://dx.doi.org/10.1080/00207390701464675

Hamidah, J. W. K. KOLABORASI PEMBELAJARAN ASSURANCE-RELEVANCEINTEREST-ASSESSMENT-SATISFACTION DENGAN THINK-TALK-WRITE UNTUK MENINGKATKAN KEMAMPUAN PENALARAN KREATIF MATEMATIK DAN MOTIVASI BERPRESTASI SISWA.

Haylock, D., 1997, Recognising mathematical creativity in schoolchildren. Zentralblatt fuer Didaktik der Mathematik, 29(3):68-74.

Limardani, G., T. Dinawati, dan A. Fatahillah. (2015). Analisis kesulitan siswa dalam menyelesaikan soal operasi aljabar berdasarkan teori pemahaman skemp pada siswa kelas VIII D SMP Negeri 4 Jember. Artikel Ilmiah Mahasiswa.1(1): 1-7.

Lithner, J. (2008). A Research Framework for Creative and Imitative Reasoning. Educational Studies in Mathematics, 67(3), 255-276.

Moleong, L.J. (2017). Metodologi Penelitian Kualitatif Edisi Revisi. Bandung: PT Remaja 
Jurnal Lebesgue : Jurnal Ilmiah Pendidikan Matematika, Matematika dan Statistika

Nyangnyang Supriatna, Ebih Ar Arhasy, Nani Ratnaningsih

Volume 2, No. 1, April 2021 hal.10-21

DOI Artikel : 10.46306/lb.v2i1.50

Rosdakarya.

Ngilawajan, D. A. (2013). Proses Berpikir Siswa SMA dalam memecahkan masalah matematika materi turunan ditinjau dari gaya kognitif field independent dan field dependent. PEDAGOGIA: Jurnal Pendidikan, 2(1), 71-83.

Noda, A. (2000). Aspectos epistemológicos y cognitivos de la resoluciónde problemas de matemáticas, bien y mal definidos. Un estudio conalumnos del primer ciclo de la ESO y maestros en formación (Tesis doctoral inédita). Universidad de la Laguna, España.

Safrida, L. N., Susanto, S., \& Kurniati, D. (2015). Analisis Proses Berpikir Siswa Dalam Pemecahan Masalah Terbuka Berbasis Polya Sub Pokok Bahasan Tabung Kelas IX SMP Negeri 7 Jember. KadikmA, 6(1).

Saracho, O. N. (1998): Editor's introduction cognitive style research and its relationship to various disciplines. International Journal of Educational Research 29, 169-172.

Slameto. (2015). Belajar dan Faktor-Faktor yang Mempengaruhinya. Jakarta: Rineka Cipta

Solso, R. L. (1995). Cognitive Psychology. Boston: Allyn and Bacon.

Sugiyono. (2019). Metode Penelitian Kuantitatif, Kualitatif, dan R\&D. Bandung : Alfabeta, CV.

Sulistiawati. (2014). Analisis kesullitan belajar kemampuan penalaran matematis siswa SMP pada materi luas permukaan dan volume limas. STKIP Surya. ISBN : 978 - $602-$ $14432-2-4$

Witkin, H.A. dkk, (1979). Field Dependent and Field Independent Cognitive Styles and Their Education Implication, New York: American Education Research Journal.

Woolfolk, A. E. (1997). Educational Psychology. Boston: Allyn \& Bacon. 